\title{
Analisa Potensi Ekstrak Etanol Andrographis paniculata, Nees sebagai Alternatif Antelmintik Fitofarmaka
}

\section{(Potential Analysis of Ethanol Extract of Andrographis paniculata, Ness as an Alternative to Anthelmintic Phytopharmaceutical)}

\author{
Indrati R, Sawitri ME, Wisaptiningsih U \\ Fakultas Peternakan, Universitas Brawijaya \\ rindrati64@gmail.com
}

\begin{abstract}
Andrographis paniculata, Nees contains saponins and tannins which are potential as an anthelmintic, and andrographolide which has also immunomodulatory activities. This study aims to evaluate the potencyal of Andrographis paniculata, Nees ethanol extract as an immunomodulatory and anthelmintic against endoparasit infestations. The materials is simplicia. Andrographis paniculata, Nees leaves wereas extracted by maceration method and analysed for the andrograpolide content. The experimental used 20 Etawah Crossbreeds goats. The study was arranged in a Completely Randomized Design (CRD) with 4 treatment groups and each treatment has 5 replications. Negative Control $=$ without treatment; Positive control = given a CurminVitPlus caplet $(500 \mathrm{mg}), \mathrm{T} 1=$ Andrographis paniculata leaf extract capsule $\mathrm{EA}=750 \mathrm{mg} ; \mathrm{T} 2=$ capsule EA $1125 \mathrm{mg}$. The parameters observed yield of Andrographis paniculata, Nees leaf ethanol extract; number of Eggs Per Gram (EPG). Data were analyzed descriptively and one-way ANOVA if significant, it will tested by the Test LSD (Least Significantly Difference). Results: capsules of ethanol extract of Andrographis paniculata, Nees (EA) reduced the number of worm eggs (EPG) which is the highest in T2 by $96,8 \%$ compared to Negative Control (NC), Positive Control (PC) and T1 treatments at a dose of $1125 \mathrm{mg}$. Conclusion: Ethanol extract of Andrographis paniculata (EA) leaves as anthelmintic phytopharmaceutical towards endoparasite infestation, at a dose of $1125 \mathrm{mg}$.
\end{abstract}

Key words: Ethanol ekstract of Andrographis paniculata, nees leaves (EA), infestation of endoparasit gastrointestinal, anthelmintica

\begin{abstract}
ABSTRAK
Andrographis paniculata, Nees mengandung zat aktif saponin dan tanin berpotensi sebagai antelmintika, dan andrographolid mempunyai aktivitas imunomodulator. Penelitian ini bertujuan menganalisa dan mengevaluasi potensi ekstrak etanol Andrographis paniculata. Nees sebagai immunomodulator dan antelmintika terhadap infestasi endoparasit. Materi dan metoda: simplisia daun Andrographis paniculata, Nees diekstrasi dengan metoda maserasi, dan penelitian eksperimental menggunakan 20 ekor kambing Peranakan Etawah. Rancangan penelitian menggunakan Rancangan Acak Lengkap (RAL) 4 kelompok perlakuan dengan 5 ulangan. Kontrol Negatif $=$ tanpa perlakuan; Kontrol Positf $=$ diberi kaplet Curmin ${ }^{\text {Vit }}$ Plus $(500 \mathrm{mg}), \mathrm{EA} 1=$ kapsul ekstrak daun Andrographis paniculata $=750 \mathrm{mg} ; \mathrm{EA} 2=\mathrm{kapsul}$ EA $1125 \mathrm{mg}$. Parameter yang diamati meliputi rendemen ekstrak dan kadar andrographolid dalam ekstrak daun Andrographis paniculata, Nees, jumlah Telur Per Gram Feses (TTGF). Data dianalisis deskriptif dan ANOVA satu arah jika berbeda nyata diuji lanjut dengan Uji BNT. Hasil: rendemen ekstrak Andrographis paniculata, Nees sebesar 1680 g atau 33,6 persen, ekstrak etanol Andrographis paniculata, Nees (EA) menurunkan jumlah telur cacing (TTGF) paling tinggi pada perlakuan EA2 (dosis $1125 \mathrm{mg}$ ) sebesar 96,8\% dibandingkan perlakuan
\end{abstract}


KN, KP dan EA1. Ekstrak etanol Andrographis paniculata, Ness (EA) dapat digunakan sebagai alternatif antelmintik fitofarmaka terhadap infestasi endoparasit, pada dosis $1125 \mathrm{mg}$.

Kata kunci: Ekstrak etanol Andrographis paniculata, Nees (EA), infestasi endoparasit gastrointestinal, antelmintika

\section{PENDAHULUAN}

Tanaman sambiloto (Andrographis paniculata,Nees) mengandung senyawa aktif utama yaitu andrograpolid, mempunyai berbagai macam khasiat sebagai hepatoprotektik , vermicidal (membunuh endoparasit gastrointestinal (GIN)), immunomodulator, flavonoid sebagai antiinflamasi, ditemukan pada bagian akar (Kardono et al. 2003), batang dan daun (Farnsworth \& Bunyapraphatsara 1992) serta herbal (Kulyal et al. 2010). Andrograpolid dapat meningkatkan daya tahan tubuh terhadap serangan endoparasit gastrointestinal (GIN). Rasa pahit dari andrograpolid diduga dapat membunuh cacing melalui perannya sebagai imunostimulan dengan meningkatkan produksi antibodi dan menyebabkan kondisi basa dalam usus sehingga cacing akan mati (Prapanza 2003; Duke 2009). Tanin yang berpotensi sebagai antihelmintik dengan cara menggumpalkan protein tubuh cacing yang dapat mengganggu metabolisme dan homeostasis pada tubuh cacing, sehingga terjadi kematian cacing (Harvey \& John 2004) dan (Sumaryono 2002). Saponin, dapat berpotensi sebagai antihelmintik bekerja dengan cara menghambat enzim asetilkolinesterase, dan bekerjanya dengan menurunkan tegangan permukaan (surface tension) pada dinding membran sehingga cacing akan mengalami paralisis otot dan berujung pada kematian (Kuntari 2000). Imunomodulator adalah senyawa tertentu yang dapat meningkatkan mekanisme pertahanan tubuh dan dapat merangsang sistem imun tubuh melalui respon imun spesifik maupun respon imun nonspesifik (Schulz 2004; (Mun'im \& Hanani 2011). Fungsi sistem imun adalah melindungi tubuh dari patogen dan menghancurkan sel-sel yang sudah tidak dikenali sebagai sel tubuh sendiri (James 2008: 124).

Penurunan produksi ternak kambing antara lain disebabkan oleh penyakit terutama gangguan parasit internal maupun eksternal. Parasit internal yang sering menyerang ternak adalah endoparasit gastrointestinal (GIN). Infeksi endoparasit GIN mengakibatkan penurunan produktivitas pada ternak yang dipelihara secara ekstentif sehingga menurunkan bobot badan sampai $38 \%$, ternak muda mengalami anemia derajat sedang sampai parah, dengan mortalitas meningkat sampai 28\% (Partoutomo 2002; Suhardono et al. 2002), kekurusan, pertumbuhan terhambat, turunnya daya tahan tubuh, dan turunnya daya kerja.

Usaha pengobatan dengan antihelmintik kimia cukup mahal dan pemberian yang tidak terkontrol dapat menimbulkan terjadinya "drug resistant". Apabila terjadi resistensi parasit akan membawa gen resisten (Ridwan et al. 2000). Zat andrograpolid sebagai nutrien suplemen dapat berfungsi meningkatkan reseptor tubuh dalam mendeteksi bendabenda (zat-zat) asing yang masuk ke dalam tubuh, meningkatkan aktivitas sistem kekebalan tubuh terhadap serangan beberapa jenis penyakit, dan penanganan imunologi. Beberapa penelitian, menunjukkan bahwa sambiloto dapat membunuh Brugia malayi (Sari \& Astari 2008), cacing Pheretima posthuma (Siddhartha et al. 2010), dan nematoda Pratylenchus vulnus (Ferris \& Zheng 1999). Pemberian andrograpolid ekstrak daun Andrographis paniculata, Nees diharapkan dapat menurunkan penggunaan obat-obatan kimiawi dan sekaligus menekan kerugian akibat serangan penyakit pada ternak. 
Tujuan penelitian ini menganalisa dan mengevaluasi potensi imunomodulator zat andrograpolide ekstrak daun Andrographis paniculata, Nees yang terukur terhadap rendemen, kadar andrograpolid dan infestasi endoparasit gastrointestinal.

\section{MATERI DAN METODE}

\section{Pelaksanaan peneltian}

Pelaksanaan penelitian terdiri dari 2 tahap yaitu 1) determinasi tanaman Andrographis paniculata Nees, proses ekstraksi, pembuatan kapsul ekstrak daun Andrographis paniculata (EA), dan analisa kandungan andrograpolide. Dilakukan di Laboratorium Fitokimia UPT Materia Medica Batu. Jawa Timur. Tahap 2 berupa, kegiatan pemeliharaan dan perlakuan ternak kambing PE di Unit Pelaksana Teknis Daerah-Hijauan Makanan Ternak (UPTD-HMT) Singosari Malang.

\section{Bahan dan materi penelitian}

\section{Tahap pertama}

Materi penelitian terdiri dari simplisia daun Andrographis paniculata $5,0 \mathrm{~kg}$, cangkang kapsul untuk ekstrak daun sambiloto (EA), etanol $96 \%$ food grade, Silica GF 254, fase gerak Chloroform: Metanol, Sacharum lactis, Mucilago Amylum Manihot. Alat: Rotary evaporator, toples, Densitometer, timbangan analitik, glass ware.

\section{Tahap kedua}

Materi penelitian terdiri yaitu kambing Peranakan Etawah jantan umur 3-4 bulan dengan kisaran berat badan 13-18 kg sebanyak 20 ekor, pakan rumput raja (King grassPennisetum purpurhoides), konsentrat, air, garam, dan kaplet Curmin ${ }^{\text {Vit }}$ Plus. Peralatan yang digunakan adalah kandang ukuran $(2,5 \times 1.25) \mathrm{m} 2$ yang terbuat dari kayu yang dilengkapi dengan tempat air minum dan tempat pakan, parang, timbangan gantung digital, timbangan berat berupa timbangan pakan kapasitas $2 \mathrm{~kg}$ dengan kepekaan $10 \mathrm{~g}$ untuk menimbang pakan, skop, ember, baskom, meter pita, cutter, gergaji besi, pisau, parang, kantong plastik, tali rafia dan seperangkat alat laboratorium, plastik untuk spesimen, cool box, glass ware. mikroskop, counting chamber, botol pot plastik, pipet pasteur, tabung sentrifus, timer, mortar, saringan, kantong plastik, kapas, dan ice box, label dan spidol.

\section{Metoda penelitian}

Proses ekstraksi etanol Andrographis paniculata Nees: Bahan simplisia yang telah diayak sebanyak $5000 \mathrm{~g}$ dan dimaserasi dengan menggunakan etanol 96,8\% food grade pada perbandingan bahan baku - pelarut 1:6 b/v selama 20 jam. Setelah itu dilakukan penyaringan dan ekstrak etanol sambiloto disimpan pada suhu $20^{\circ} \mathrm{C}$. Hasil ekstraksi serbuk daun sambiloto (Andrographis paniculata Ness) dengan rendemen ekstrak kental sebesar $1680 \mathrm{~g}$ atau sama dengan 33.6 persen. Hasil analisis kadar andrograpolide yang tersari dengan metode KLT sebesar 1,11 $\pm 0,14 \%$. 


\section{Proses kapsulasi}

Andrographis paniculata Ness: ekstrak kental hasil ekstraksi ditambahkan Sacharum lactis dan Mucilago Amylum Manihot, kemudian dimasukkan dalam oven pada suhu $\leq$ $40^{\circ} \mathrm{C}$ selama 2 hari. Hasil ekstrak serbuk kering sebanyak 317.250 mg siap dimasukkan kedalam cangkang kapsul ukuran sesuai dosis perlakuan.

\section{Penelitian eksperimental lapang melaksanakan pemeliharaan dan perlakuan ternak kambing peranakan etawah}

Sebelumnya melakukan persiapan ternak diadaptasi selama 1 minggu. Pemberian pakan alami 3 kali sehari yaitu pada pagi jam 08.00 wib konsentrat, pada siang jam 10.00 wib dan sore jam 16.00 wib rumput raja (Pennisetum purpurhoides), air minum diberikan secara adlibitum. Kambing ditempatkan dalam 4 kelompok perlakuan. Setiap kelompok kandang berisi 5 ekor kambing PE. yaitu KN, CVP, EA1, EA2. Ekstrak daun Andrographis paniculata Ness (EA) bentuk kapsul ekstrak kering diberikan peroral. Dosis pemberian kapsul EA setiap kelompok sebagai berikut:

Perlakuan Kelompok Negatif (Non Treatmen) = NT, perlakuan Kelompok Positip

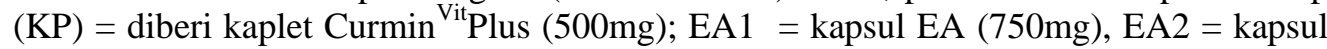
EA (1125mg). Sebelum pemberian kapsul EA setiap ekor kambing diperiksa jumlah telur cacing TTGF) Mc Master melalui feses menggunakan uji apung (Floating Methode). Pengambilan data dilakukan setiap 2 minggu selama 10 minggu: pengambilan feses, Parameter yang diukur jumlah telur tiap gram feses cacing (TTGF)

\section{Analisa data}

Penelitian tahap 1: Hasil analisa dievaluasi secara deskriptif. Penelitian tahap 2: Analisis kejadian helmintiasis menggunakan data deskriptif dari jumlah sampel positif endoparasit, jenis telur cacing endoparasit nematoda yang ditemukan tiap gram feses (TTTGF). Perbedaan perlakuan di analisa dengan mengunakan ANOVA (Analysis of Variant) yang dilanjutkan dengan uji Beda Nyata Terkecil (Mattjik dan Sumertajaya, 1999).

\section{HASIL DAN PEMBAHASAN}

\section{Analisis penelitian tahap pertama}

\section{Hasil ekstraksi dan penetapan kadar andrograpolid}

Hasil ekstraksi serbuk daun sambiloto (Andrographis paniculata Ness) sebanyak $5000 \mathrm{~g}$ dengan rendemen ekstrak kental sebesar $1680 \mathrm{~g}$ atau sama dengan 33.6 persen. Hasil lebih tinggi dari Cahyaningsih dkk (2007) bahwa 1kg Andrographis paniculata Ness rendemen $80 \mathrm{~g}$ atau $8 \%$ ekstraksi tanaman sambiloto metode maserasi menggunakan pelarut metanol pro analisis selama 3 hari. Hasil penetapan kadar andrograpolid dengan metode maserasi sebesar sbagai berikut: 
Tabel 1. Hasil penetapan kadar andrograpolid metode KLT

\begin{tabular}{llc}
\hline \hline No.Sampel & Sampel tanaman & Rataan \pm SD andrograpolid (\%) \\
\hline 1 & Andrographis paniculata, Ness* & $1,14 \pm 0,04$ \\
2 & Andrographis paniculata, Ness* & $1,09 \pm 0,02$ \\
3 & Andrographis paniculata, Ness* & $1,11 \pm 0,04$ \\
\hline
\end{tabular}

* Laboratorium Fitokimia UPT Materia Medica Batu

Hasil pada Tabel 1menunjukkan bahwa tidak berbeda jauh dengan beberapa hasil penelitian oleh Raina et al. (2007), berkisar 1,14\% - 2,50\%, Pandey et al. (2010) bahwa kandungan andrograpolid dalam daun kering herba Andrographis paniculata,Ness berkisar $1,04 \%-2,24 \%$. Perbedaan kandungan andrograpolid disebabkan oleh antara lain umur, tempat tumbuh, dan metode analisis yang digunakan. Waktu ekstraksi memberikan pengaruh terhadap kadar andrograpolid di dalam ekstrak etanol Andrographis paniculata, Ness terpurifikasi. Semakin lama waktu ekstraksi maka semakin besar kadar andrografolid di dalam ekstrak etanol terpurifikasi sampai pada batas tertentu, kemudian mengalami penurunan.

Andrographolide merupakan senyawa aktif utama dalam sambiloto, dan mempunyai berbagai macam khasiat sebagai hepatoprotective, anti-inflammatori, vermicidal (membunuh cacing gastrointestinal), immunomodulator, ditemukan pada bagian akar (Kardono et al. 2003), batang dan daun (Kulyal et al. 2010).

\section{Pembuatan kapsul ekstrak etanol Andrographis paniculata, Ness}

Andrographis paniculata,Ness dapat dimanfaatkan dalam bentuk segar, simplisia, kapsul, serbuk, infus, kapsul ekstrak kental, dan kapsul ekstrak kering. Untuk meningkatkan mutu ekstrak kering dan mempercepat waktu pengeringan ekstrak kental hasil ekstraksi Andrographis paniculata,Ness sebanyak $1680 \mathrm{~g}=1680000 \mathrm{mg}$ ditambahkan Sacharum lactis dan Mucilago Amylum Manihot kemudian dimasukkan dalam oven pada suhu $\leq 40^{\circ} \mathrm{C}$ selama 2 hari. Hasil ekstrak serbuk kering sebanyak $317.250 \mathrm{mg}$ siap dimasukkan kedalam cangkang kapsul sesuai dosis perlakuan. Dosis perlakuan EA1:750 mg, EA2:1125mg, serta Kontrol Negatif (NT): tanpa EA, KP: kaplet Curmin ${ }^{\text {Vit }}$ Plus 500mg.

\section{Analisis Penelitian tahap kedua}

\section{Analisis potensi ekstrak etanol Andrographis paniculata, Ness (EA) sebagai antelmintika}

Jenis endoparasit nematoda gastrointestinal yang diketemukan melalui pemeriksaan sampel feses menggunakan metode Apung McMaster (Abdurrahman \& Daud 2013) yang dilakukan setiap 2 minggu terdapat 6 jenis telur endoparasit nematoda GIN yaitu yaitu Trichuris sp, Oesophagustomum sp, Strongylus dan Strongyloides sp, Ookista Eimiria sp, Trychostongylus sp, dan Haemonchus sp. spp, Trichostrogylus spp. Hal ini sesuai pada temuan lain oleh Pfukenyi \& Mukaratirwa (2013), demikian juga oleh Purwaningsih et al. (2017). 
Tabel 2. Rata-rata jumlah telur tiap gram feses (TTGF) setelah perlakuan pemberian EA dengan dosis berbeda

\begin{tabular}{lcccc}
\hline \hline \multirow{2}{*}{ Parameter } & \multicolumn{4}{c}{ Perlakuan } \\
\cline { 2 - 5 } & $\begin{array}{c}\text { Non Treatment } \\
(\mathrm{NT})\end{array}$ & $\begin{array}{c}\text { Curmin Vit Plus: } \\
500 \mathrm{mg}(\mathrm{CVP})\end{array}$ & $\begin{array}{c}\text { EA1 } \\
(750 \mathrm{mg})\end{array}$ & $\begin{array}{c}\text { EA2 } \\
(1125 \mathrm{mg})\end{array}$ \\
\hline $\begin{array}{l}\text { TTGF } \\
\text { nematoda }\end{array}$ & $155,6 \pm 74,36^{\mathrm{a}}$ & $134 \pm 128,59^{\mathrm{a}}$ & $103,2 \pm 96,131^{\mathrm{a}}$ & $104,6 \pm 154,30^{\mathrm{a}}$ \\
\hline
\end{tabular}

Keterangan: Tidak ada superskrip huruf kecil menunjukkan tidak berbeda nyata $(\mathrm{P}>0.05)$. Kontrol Negatif $=\mathrm{NT}, \mathrm{CVP}=$ Kontrol Positip dengan pemberian Curmin Vit Plus: 500mg, $\mathrm{EA} 1=750 \mathrm{mg}, \mathrm{EA} 2=1125 \mathrm{mg}$

Semua sampel feses perlakuan NT, CVP, EA1, EA2 teridentifikasi mengalami infestasi endoparasit nematoda GIN campuran beberapa jenis endoparasit. Menurut Subronto \& Tjahajati (2001), Razak (2007) bahwa keberadaan endoparasit nematoda GIN bisa diidentifikasi melalui pemeriksaan feses, apabila ditemukan telur pada feses, maka bisa didiagnosa adanya endoparasit nematoda GIN pada ternak. Beberapa faktor yang mempengaruhi timbulnya penyakit endoparasit pada hewan ternak antara lain geografis, manajemen pemeliharaan dan penggunaan antelmintik.

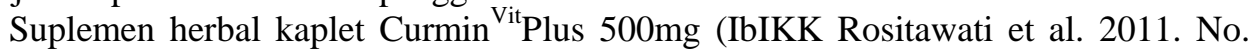
Paten IDP000040583) sebagai pembanding perlakuan pemberian EA1 $=750 \mathrm{mg}$, dan EA2 $=1125 \mathrm{mg}$, karena zat aktif yang terkandung dalam kaplet Curmin ${ }^{\text {Vit }}$ Plus mempunyai fungsi antelmintika dan imunomodulator analog dengan fungsi ekstrak Andrographis paniculata, Ness (EA).

Pada perlakuan Curmin Vit Plus rata-rata TTGF $(134 \pm 128,59)$ lebih tinggi dari EA1 $\left(103,2 \pm 96,131^{\prime}\right.$ dan EA2 $(104,6 \pm 154,30)$, hal ini diduga dosis herbal kaplet Curmin ${ }^{\text {Vit }}$ Plus (500mg) lebih rendah daripada dosis kapsul EA1 dan EA 2 walaupun secara statistik tidak berbeda nyata. Secara statistik pemberian EA berpengaruh nyata $(\mathrm{P}<0,05)$ terhadap penurunan jumlah TTGF dibanding dengan NT. Secara angka tampak bahwa penurunan jumlah TTGF pada perlakuan EA2 lebih besar dibanding pada perlakuan EA1 (Gambar 1). Pada semua kelompok perlakuan NT, CVP, EA1, dan EA2, jumlah TTGF antara 1499 artinya derajat infestasinya tergolong ringan (Thienpont et al. 1995).

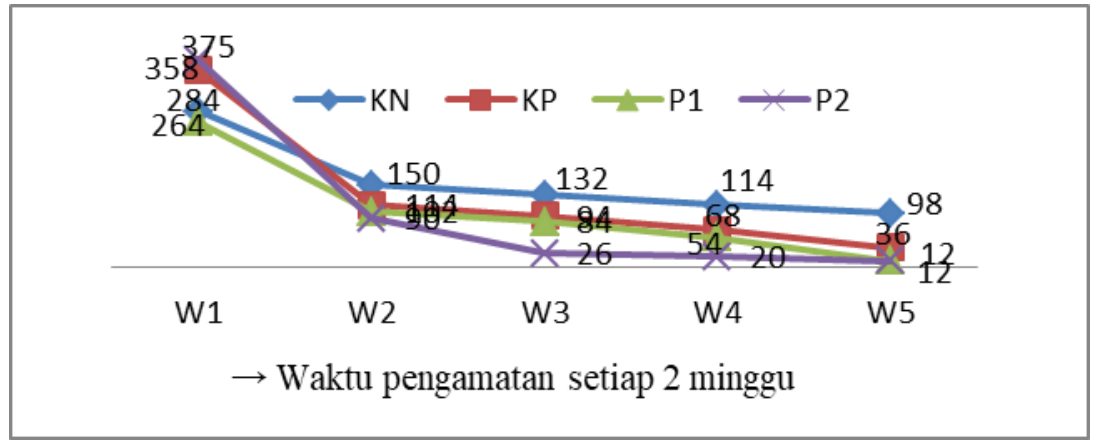

Gambar 1. Kurva jumlah TTGF dari feses kambing dari 10 minggu selama 10 minggu

Berdasarkan Gambar 1 (dibawah) pengamatan minggu ke-2 sampai minggu ke-10 semua perlakuan mengalami penurunan jumlah TTGF, pada perlakuan NT penurunan lebih rendah sebesar 59, $86 \%$ (TTGF awal-akhir: 284-98) dari perlakuan CVP: 
89,94\% (358-36), EA1: 94,45\% (264-12), dan EA2: 96,8\% (375-12). Penurunan TTGF paling tinggi sampai akhir pengamatan terjadi pada perlakuan EA2 yaitu sebesar 96,8\%. Hal ini dapat dikatakan dosis EA: $1125 \mathrm{mg}$ yang terbaik sebagai imunosupresan/antelmimtika terhadap infestasi endoparasit nematoda gastrointestinal.

Menurut Kuntari (2008), Harvey \& John (2004); Duke (2009) Ekstrak etanol Andrographis paniculata, Ness mengandung senyawa aktif saponin, tannin, dan zat andrograpolid berperan sebagai imunosupresan dan antelmintika dapat membunuh cacing dengan menimbulkan suasana basa pada usus sehingga tidak nyaman bagi kehidupan cacing, saponin berpotensi sebagai antelmintik yaitu dengan cara menghambat enzim asetilkolin esterase maka cacing mengalami paralisis otot, dan tanin dapat menggumpalkan protein pada dinding cacing sehingga menyebabkan gangguan metabolisme dan homeostasis cacing dan penghambatan terhadap migrasi larva cacing.

\section{KESIMPULAN}

Rendemen ekstrak Andrographis paniculata, Ness sebesar $1680 \mathrm{~g}$ atau 33.6 persen dengan kandungan kadar andrograpolid 1,11 \pm 0,02. Ekstrak etanol Andrographis paniculata,Ness berpotensi sebagai imunosupresan dan antelmintik terhadap infestasi endoparasit nematoda (GIN) dengan penurunan TTGF sebesar 96,8\% pada dosis EA: $1125 \mathrm{mg}$.

\section{DAFTAR PUSTAKA}

Abdurrahman, Daud. 2013. McMaster - hitung jumlah telur cacing secara kuantitatif [Internet]. [diakses 3 Maret 2014]. Tersedia dari: http://mltunite.blogsp.ot.com/2013/12/mcmasterhitung-jumlah-telur-cacing.html.

Anonim. 2012. Pedoman umum pengendalian dan penanggulangan penyakit parasit dan kematian pedet. Jakarta (Indonesia): Direktorat Kesehatan Hewan Kementerian Pertanian Republik Indonesia.

Baratawidjaja GK, Rengganis I. 2012. Imunologi dasar. Jakarta (Indonesia): Badan Penerbit FK UI. hlm. 29, 116-129, 371, 517.

Corwin JE. 2000. Patofisiologi. Jakarta (Indonesia): EGC.

Cahyaningsih, Riandci R, Iswantini D. 2012. Ekstrak sambiloto (Andrographis paniculata, Ness) menurunkan jumlah skizon, mikrogamet, makrogamet, dan oosista Eimeria tenella. J Veteriner. 13:322-329.

Duke J. 2009. Phytochemical and ethnobotanical Database-ANDROGRAPHLIDE [Internet]. [diakses 3 Maret 2014]. Tersedia dari: http://sun.arsgri.gov:8080/npgspub/xsq1/duke/chemdisp.xsql?chemicalANDROGRAPHOLIDE.

Farnsworth NR, Bunyapraphatsara N. 1992. Recommended for primary health care system. Bangkok (Indonesia): Prachachon Company.

Harvey WF, John UL. 2005. Kamala [Internet]. [diakses 3 Februari 2010]. Tersedia dari: http://www.ibiblio.org/herdmeb/eclectic/kings/mallotus_phil.html.

James, Joyce. 2008. Prinsip-prinsip sains untuk keperawatan. M Perarson International edition, New York. Jakarta (Indonesia): Penerbit Erlangga.

Kardono LBS, Artanti N, Dewiyanti ID, Basuki T. 2003, Selected indonesian medicinal plants: Monograph and descriptions. Jakarta (Indonesia): Grasindo. hlm. 117-153. 
Kulyal P, Tiwari UK, Shukla A, Gaur AK. 2010. Chemical constituent isolated from Andrographis paniculata. Ind J Chemist. 49B:356-359.

Kuntari T. 2008. Daya antihelmintik air rebusan daun ketepeng (Cassia alata. L) terhadap cacing tambang anjing in vitro. Logika. 5:23-26.

Manoj A, Urmila A, Bhagyashri W, Meenakshi V, Akshaya W, Gujar N. Kishore. 2008. Anthelmintic activity of Ficus benghalensis. Ind J Green Pharm. 2:170-172.

Mattjik AA, Sumertajaya M. 1999. Perancangan percobaan dengan aplikasi SAS, SPSS dan Minitab. Bogor (Indonesia): IPB Press.

Mehr MA, Hassanabdi A, Nassiri M, Kermanshahi. 2014. Suplementasi of clove essential oil and probiotic to the broiler'son performance, carcass and blood components. J Appl Anim Sci. 4:117-122.

Mun'im A, Hanani E. 2011. Fitoterapi dasar, 42. Jakarta (Indonesia): Dian Rakyat.

Nafrialdi RS. 2007. Imunomodulator, imunosupresan, dan imunostimulan. Dalam: Farmakologi dan terapi. Edisi Kelima. Jakarta (Indonesia): Balai Penerbit FKUI. hlm. 757-764.

Partoutomo S. 2004. Pengendalian parasit dengan genetic hostresistance. Wartazoa. 14.

Pandey AK, Mandal AK, 2010. Variation in morphological characteristic and andrographolide content in Andrographis paniculata (Burm.f.) Ness of central India. Iran J Energy Enviroment. 1:165-169.

Pfukenyi DM, Mukaratirwa S. 2013. A review of the epidemiology and control of gastrointestinal nematode infections in cattle in Zimbabwe. Onderstepoort J Vet Res. 80:612. doi: http://dx.doi.org/10.4102/ojvr.v80i1.612.

Purbowati E, Sutrisno CI, Baliarti E, Budhi SPS, Lestariana W. 2007. Pengaruh pakan N komplit dengan kadar protein dan energi yang berbeda pada penggemukan domba lokal jantan s/ecara feedlot terhadap konversi pakan. Prosiding Seminar Nasional Teknologi Peternakan dan Veteriner. Bogor (Indonesia): Pusat Penelitian dan Pengembangan Peternakan.

Purwaningsih, Noviyanti, Sambodo P. 2017. Infestasi cacing saluran pencernaan pada kambing kacang peranakan ettawa di Kelurahan Amban Kecamatan Manokwari Barat Kabupaten Manokwari Provinsi Papua Barat. J Ilmiah Peternakan Terpadu. 5:8-12.

Ridwan Y, Satrija F, Retnani EB, Tiuria R. 2000. Haemonchus contortus resistant to albendazole on sheep farm in Bogor. Abstract in International Conference on Soil Transmitted Helminth Control and Workshop on Indonesian Association of Parasitic Disease Control. Bali, February 21-24, 2000.

Raina AP, Kumar A, Pareek SK. 2007. HPTLC analysis of hepatoprotective diterpenoid andrographolide from Andrographis paniculata Nees (Kalmegh). Ind J Pharm Sci. 69:473-475.

Razak RA. 2007. Gambaran leukosit ayam yang diinfeksi Eimeria tenella setelah pemberian ekstrak sambiloto (Andrographis paniculata Ness) dosis bertingkat. Bogor (Indonesia): Fakultas Kedokteran Hewan, Institut Pertanian Bogor.

Roitt I. 2002. Imunologi. Edisi ke-8. Alida H, Liliana K, Samsuridjal D, Siti BK, Yoes PD, penerjemah. Jakarta (Indonesia): Penerbit Widya Medika. hlm. 16-18.

Schulz V, et al. 2004. Rational phytotheraphy. Mager 5th. Berlin (Germany): Springer Verlag.

Siddhartha S, Archana M, Jinu J, Pradeep M. 2010. Anthelmintic potential of Andrographis paniculata, Cajanus cajan and Silybum marianum. Pharm J. 2:6. 
Suhardono, Beriajaya, Yulistiani D. 2002 . Infeksi cacing nematoda saluran pencernaan pada domba yang digembalakan secara ekstensif di daerah padat ternak di Jawa Barat. Prosiding Seminar Nasional Teknologi Peternakan dan Veteriner. Bogor (Indonesia): Pusat Penelitian dan Pengembangan Peternakan. hlm. 370-375.

Tizard IR. 1988. Pengantar imunologi veteriner. Hardjosworo M, penerjemah. Terjemahan dari: An Introduction to Veterinary Immunology. Surabaya (Indonesia): Penerbit Universitas Airlangga.

Thienpont D, Rochette F, Vanparijs OFJ. 1995. Diagnosing helminthiasis by coprological examination. Beerse (Belgium): Jansenn Reseach Foundation.

Waller PJ. 1993. Control strategies to prevent resistance. Vet Parasitol. 46:133-142.

Waller PJ, Echevarria F, Eddi C, Maciel S, Nari A, Hansen JW. 1996. The prevalence of anthelmintic resistance in nematode parasite of sheep in Southern Latin America: General Overview. Vet Parasitol. 62:181-187. 